\title{
Investigation the Technology Usage Level of Teacher Candidates
}

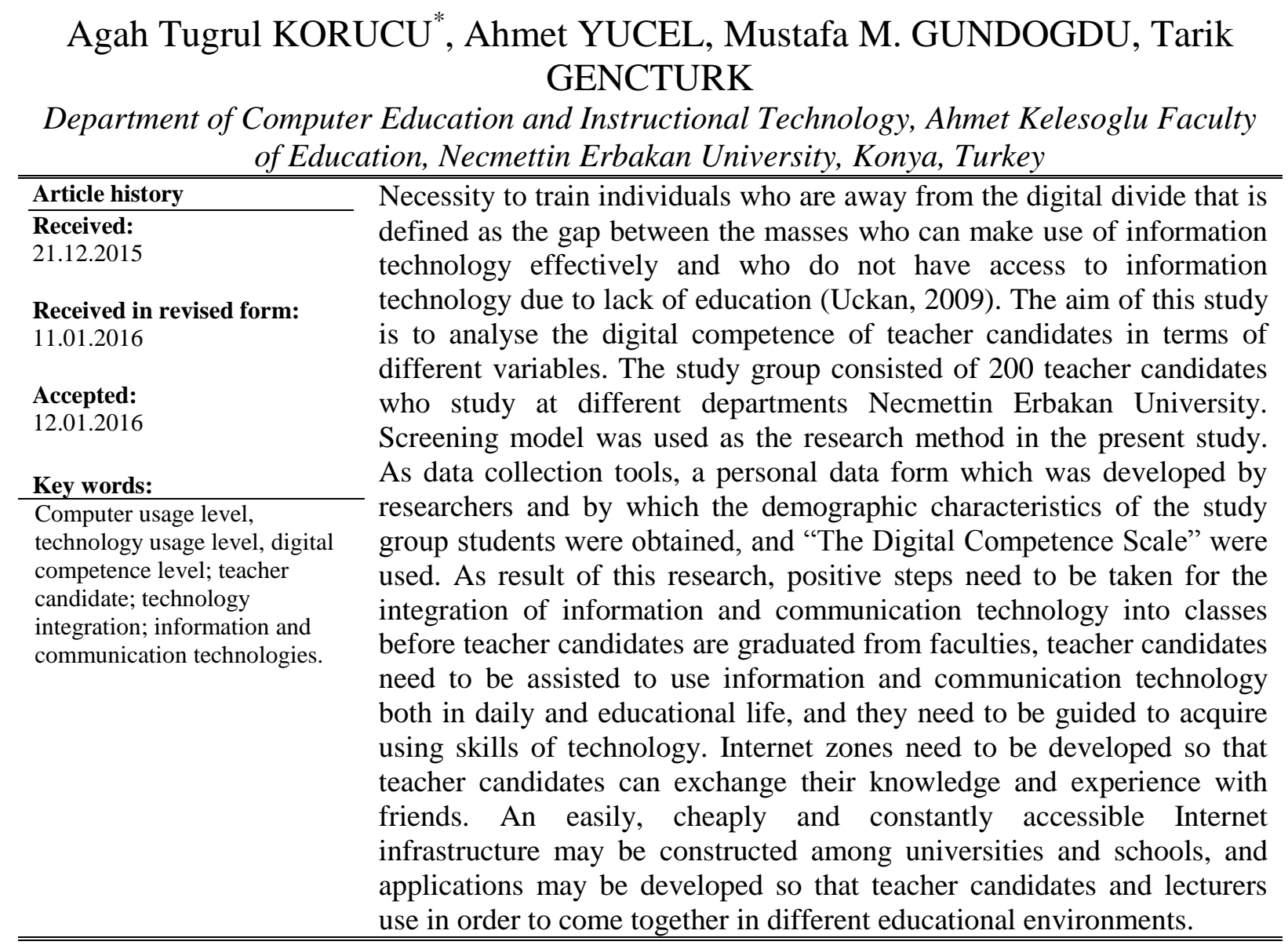

\section{Introduction}

The age we're living in is called the information age and the modern-day communities are called information communities owing to the advantages in all fields of information technologies renewed with the development of technology and sub-structure in today's world. The 21 st Century is called the technology age and all communities in today's world are affected by the technological developments. Particular changes are being experienced in the light of these developments. Educational expectation is now possible for the educational system to meet the expectations and progresses in the communities with the help of technology (Erkan, 2004; Ala-Mutka, Punie \& Redecker, 2008). Developments in all areas, especially in today's society has influenced the field of information and communication technologies has occurred since 1980. Information and communication technologies are playing a very important role in the advancement of knowledge (Açıkgöz, 2005). The 
education system is also affected by these developments. Information and communication technologies in the targeted students at least in the field of information technology literacy levels and is expected to be able to use information and communication technologies in the profession (Bawden, 2001; Göktaş, Yıldırım \& Yıldırım, 2008; Krumsvik, 2008).

Information and communication technologies are located in a large part of our lives. Terms used digital technology to transmit and store large fraction of the information technologies. Computers, the Internet, mobile devices and "Web 2.0" technologies, digital technologies are called (O'reilly, 2007; Timur, Timur \& Akkoyunlu, 2014). The optimal use of digital technologies is to be qualified digital. Competence success in certain activities that individuals' views about the core (Makinen, 2006). Digital competence of digital technology is the ability to help advance the consolidation of the position information of individuals and communities in their lives. Individuals with unlimited possibilities while technological developments are needed for a productive life, especially the exchange of information and leads the skills of individuals. The ability to use digital technologies is one of these developments. Development of digital literacy is required for them to be at an appropriate level in order to detect individuals towards other people and growing world (Y1ldiz, Kahyaoğlu \& Kaya, 2012). The choice of profession. Integrated or non-integrated technologies in individuals living in the community will not be able to have specific qualifications in the education system, depending on the situation. As a result, the individual will be deducted automatically behind the economic and social age. Educational institutions play an important role in preparing individuals for life with the development of digital technology in today's world. It is necessary to use digital technology to develop social competence. Young is a digital community should be considered important to create (Akkoyunlu, Soylu \& Çağlar, 2010).

Education occupies a particular place in raising manpower necessary for information community by providing the minimization of technological differences of bigger masses and the augmentation of personal skills. For this reason, it is necessary that the digital technologies are used in learning environments by students and instructors (Zhou, Burgoon, Zhang \& Nunamaker, 2004). The acquisition of these skills by the instructors is necessary for the raising of individuals reached digital competence in educational institutions. In order to successfully complete the necessary change in educational institutions and to enhance the digital literacy skills of instructors, a life-long learning environment should be established (Akkoyunlu \& Soylu, 2010).

Therefore the determination of digital competence levels of prospective instructors is essential since it is one of the most important components in the integration process of information and communication technologies (ICT) into education. The more prospective instructors deal with ICT tools, the more they spend time for their digital competences and the more they receive education regarding how to integrate ICT tools into their branch lessons; their digital competence levels will increase and ICT integration will be enhanced (Chen, 2004; Jung, 2005; HU \& Kuh, 2002). Based on this perspective, the goal of this study is the analysis of digital competence situations of prospective instructors in terms of possession durations of mobile devices, weekly internet usage durations, socio-economic levels of grades, internet possession of grades. Also, Is there a reasonable correlation between the academic success grades and digital competence situations of prospective instructors? Within this scope, responses of the following survey questions are sought: 
(1) Do digital competence situations of prospective instructors differ in terms of their possession durations of mobile devices?

(2) Do digital competence situations of prospective instructors differ in terms of their weekly internet usage durations?

(3) Do digital competence situations of prospective instructors differ in terms of socioeconomic levels of grades?

(4) Do digital competence situations of prospective instructors differ in terms of internet possession of grades?

(5) Is there a reasonable correlation between the academic success grades and digital competence situations of prospective instructors?

\section{Method}

\section{The Model of the Study and the Workgroup}

Conducted according to the screening model, this study comprises of 200 students in total; 50 students from the Department of Computer and Instructional Technologies, 50 students from the Department of Art Teaching, 50 students from the Department of Preschool Teaching and 50 students from the Department of Biology Teaching within the body of Ahmet Kelesoglu Faculty of Education, University of Necmettin Erbakan in the academic year 2014-2015 Spring.

\section{Data Collection Tools}

'Digital Competence Scale' developed by Akkoyunlu, Y1lmaz Soylu and Caglar (2010) and which is a personal information form from which demographical data of workgroup students is obtained is used as the data collection tool in this study. The scale is 7 point likert scale; 1 means 'Do not agree at all', 4 means 'Uncertain' and 7 means 'Totally agree'. This is a scale of 45 articles and four dimensions. Cronbach Alfa coefficients are calculated for the findings regarding the credibility of the scale and the following figures are found; 0.86 for the entire scale, 0.94 for the first sub-dimension (Awareness), 0.84 for the second sub-dimension (Motivation), 0.78 for the third sub-dimension (Technical Access) and 0,81 for the fourth sub-dimension (Competence).

\section{Data Analysis}

Data obtained in scope of the study are analyzed via SPSS (The Statistical Package for The Social Sciences) package program and all hypotheses are tested at 0.95 confidence level $(\mathrm{p}=0.05)$. Parametric tests are used during the data analysis because the data correspond to parametric test assumptions $(\mathrm{N}=200)$. Within this concept, tests used for each sub-goal are explained below. Demographical data collected from the participants are clarified with descriptive statistical methods. T-test for independent samples is used in order to test whether the competence level differs reasonably according to possession of computer and internet of the participants. Moreover, single factorial analysis of variance (one way anova) for unrelated samples is used in order to test whether the grades obtained by the participants from the scale differs reasonably according to the weekly internet usage durations, socio-economic levels, class levels and departments, mobile device possession durations and mobile device usage efficiency situations of the participants. Furthermore, simple correlation technique is used for the determination of the relation between the general academic success and digital competence situations of the students. Correlation coefficient states two figures. First of these figures is the direction, second is the magnitude. If the correlation coefficient is 1.00 , that 
means there is an excellent positive relation; if it is -1.00 , that means there is an excellent negative relation. If the correlation coefficient shows 0.00 , that means there is no relation. Although there isn't a complete consensus regarding the interpretation of correlation coefficient in terms of magnitude in the literature, it may be appropriate to define the following; high relation if the correlation coefficient's absolute value is between $0.70-1.00$; medium relation if it is between 0.70-0.30; and low relation if it is between $0.30-0.00$ (Büyüköztürk, 2011, p. 32; Karasar, 1999).

\section{Findings and Interpretations} workgroup.

Table 1 demonstrates the descriptive results regarding the genders of students in the

Table 1. Genders of the Workgroup

\begin{tabular}{ccc}
\hline Gender & $\mathrm{N}$ & $\%$ \\
\hline Male & 78 & 39,0 \\
Female & 122 & 61,0 \\
\hline Total & 200 & 100,0 \\
\hline
\end{tabular}

As it is clear in Table 1, among the students who participated in the study, 78 are male (39\%) and 122 are female $(61 \%)$.

Table 2 involves the findings concerning whether the grades which participants obtained from the digital competence scale reasonably differ or not according to the mobile device possession durations of students.

Table 2. Anova results of grades according to mobile device possession durations

\begin{tabular}{|c|c|c|c|c|c|c|}
\hline \multicolumn{2}{|c|}{ Rating } & $\mathrm{N}$ & $\bar{X}$ & \multicolumn{3}{|c|}{$\mathrm{S}$} \\
\hline \multicolumn{2}{|c|}{$0-2$ years } & 33 & 149,6667 & & 25,28422 & \\
\hline \multicolumn{2}{|c|}{ 2-4 years } & 29 & 153,8966 & & 21,38649 & \\
\hline \multicolumn{2}{|c|}{4 years and over } & 138 & 161,2246 & & 24,77962 & \\
\hline \multicolumn{2}{|c|}{ Total } & 200 & 158,2550 & & 24,71831 & \\
\hline & $\begin{array}{l}\text { Variance } \\
\text { Resource }\end{array}$ & $\begin{array}{l}\text { Total of } \\
\text { Squares }\end{array}$ & sd & $\begin{array}{c}\text { Average of } \\
\text { Squares }\end{array}$ & $\mathrm{F}$ & $\mathrm{p}$ \\
\hline \multirow{3}{*}{ Rating } & Inter-groups & 4201,936 & 2 & 2100,968 & 3,526 & 031 \\
\hline & Intra-groups & 117386,059 & 197 & 595,868 & & \\
\hline & Total & 121587,995 & 199 & & & \\
\hline
\end{tabular}

As it is clear in Table 2, according to the findings obtained using the single factorial variance analysis (one way anova) for unrelated samples, there is a reasonable difference among the grades of participants in terms of their mobile device possession durations $[F(2-197)=3,526$, $\mathrm{p}<.05]$. In other words, the digital competence situations of the participants differ in terms of their mobile device possession durations.

Table 3 includes the findings concerning whether the grades which participants obtained from the digital competence scale reasonably differ or not according to the weekly internet usage durations of students.

Table 3. Anova results of grades according to weekly internet usage durations

$\begin{array}{llll}\text { Weekly Internet usage } & \mathrm{N} & \mathrm{X} & \mathrm{S}\end{array}$




\begin{tabular}{|c|c|c|c|c|c|c|}
\hline \multicolumn{7}{|c|}{ durations } \\
\hline \multicolumn{2}{|c|}{$0-3$ hours } & 20 & 143,7000 & & 28,93204 & \\
\hline \multicolumn{2}{|c|}{ 3-6 hours } & 49 & 151,9592 & & 22,37275 & \\
\hline \multicolumn{2}{|c|}{ 6-9 hours } & 45 & 158,9556 & & 22,95446 & \\
\hline \multicolumn{2}{|c|}{9 hours and over } & 86 & 164,8605 & & 23,89199 & \\
\hline \multirow[t]{2}{*}{ Total } & & 200 & 158,2550 & & 24,71831 & \\
\hline & $\begin{array}{l}\text { Variance } \\
\text { Resource }\end{array}$ & $\begin{array}{l}\text { Total of } \\
\text { Squares }\end{array}$ & sd & $\begin{array}{c}\text { Average of } \\
\text { Squares }\end{array}$ & $\mathrm{F}$ & $\mathrm{p}$ \\
\hline \multirow{3}{*}{$\begin{array}{c}\text { Weekly } \\
\text { internet } \\
\text { usage } \\
\text { durations }\end{array}$} & Inter-groups & 9953,640 & 3 & 3317,880 & 5,825 &, 001 \\
\hline & Intra-groups & 111634,355 & 196 & 569,563 & & \\
\hline & Total & 121587,995 & 199 & & & \\
\hline
\end{tabular}

As it is clear in Table 3, according to the findings obtained using the single factoral variance analysis (one way anova) for unrelated samples, there is a reasonable difference among the grades of participants in terms of their weekly internet usage durations $[F(3-196)=5,825$, $\mathrm{p}<.05]$. In other words, the digital competence situations of the participants differ in terms of their weekly internet usage durations.

Table 4 includes the findings concerning whether the grades which participants obtained from the digital competence scale reasonably differ or not according to the socio-economic levels of students.

Table 4. Anova results of grades according to socio-economic levels

\begin{tabular}{|c|c|c|c|c|c|c|}
\hline \multicolumn{2}{|c|}{ Socio-economic levels } & $\mathrm{N}$ & $\bar{X}$ & \multicolumn{3}{|c|}{$\mathrm{S}$} \\
\hline $\mathrm{Bad}$ & & 5 & 182,8000 & & 24,89377 & \\
\hline Medium & & 171 & 156,4327 & & 24,46895 & \\
\hline Good & & 24 & 166,1250 & & 23,08644 & \\
\hline \multirow[t]{2}{*}{ Total } & & 200 & 158,2550 & & 24,71831 & \\
\hline & $\begin{array}{l}\text { Variance } \\
\text { Resource }\end{array}$ & $\begin{array}{l}\text { Total of } \\
\text { Squares }\end{array}$ & sd & $\begin{array}{c}\text { Average of } \\
\text { Squares }\end{array}$ & $\mathrm{F}$ & $\mathrm{p}$ \\
\hline \multirow{3}{*}{$\begin{array}{c}\text { Socio- } \\
\text { economic } \\
\text { levels }\end{array}$} & Inter-groups & 5066,593 & 2 & 2533,297 & 4,283 &, 015 \\
\hline & Intra-groups & 116521,402 & 197 & 591,479 & & \\
\hline & Total & 121587,995 & 199 & & & \\
\hline
\end{tabular}

As it is clear in Table 4, according to the findings obtained using the single factoral variance analysis (one way anova) for unrelated samples, there is a reasonable difference among the grades of participants in terms of their socio-economic levels $[F(2-197)=4,283$, p>.05]. In other words, the digital competence situations of the participants differ in terms of their socioeconomic levels.

Table 5 includes the findings concerning whether the grades which participants obtained from the digital competence scale reasonably differ or not according to the internet possession situations of students.

Table 5. Results (t-test for unrelated samples) of grades according to internet possession situations

\begin{tabular}{|c|c|c|c|c|c|c|}
\hline Groups & $\mathrm{N}$ & $\bar{X}$ & $\mathrm{~S}$ & $\mathrm{Sd}$ & $\mathrm{t}$ & $\mathrm{p}$ \\
\hline Yes & 179 & 159,95 & 25,01 & 198 & 2,892 &, 004 \\
\hline No & 21 & 143,76 & 16,20 & & & \\
\hline
\end{tabular}

The average of grades which participants obtained as a result of digital competence scale are 
different (average of those who possess internet is $\bar{X}=159,95$; average of those who don't possess internet is $\bar{X}=143,76$ ), thus as it is clear in Table 5, the result is $.004<.05$ for $* \mathrm{p}<.05$ relevance level so the result is reasonable. In other words, the grades participants obtained differ reasonably in terms of their situations of internet possession and the result is meaningful.

Findings regarding the relationship between the success grades of students and their digital competence situations: the relationship between the academic success grades and digital competence situations (simple correlation);

Simple correlation technique is used in the determination of the relationship between the academic success grades and digital competence situations. Table 6 includes the findings regarding the relationship between academic success grades and digital competence situations of students.

Table 6. Relationship between academic success grades and digital competence situations

\begin{tabular}{ll}
\hline & Academic success grades \\
\hline Digital competence situations & $.139^{*}$ \\
\hline Correlation is reasonable in 0.05 level. &
\end{tabular}

As it is clear in Table 6, there is a low, positive and reasonable relationship between the academic success grades and digital competence grades of students, $r=.139, \mathrm{p}<.05$. Accordingly, it can be considered that as the academic success grades increase, so does the digital competence situation. When the determination coefficient $\left(r^{2}=.019\right)$ is considered, it can be deducted that the $1,9 \%$ of total variance in the increase of academic success grades originates from the digital competence situations of students.

\section{Conclusion and Suggestions}

By result of this study, there is a reasonable difference in terms of mobile device possession durations $[\mathrm{F}(2-197)=3,526, \mathrm{p}<.05]$. In other words, digital competence situations of participants differ in terms of mobile device possession durations. There is a reasonable difference in terms of weekly internet usage durations $[\mathrm{F}(3-196)=5,825, \mathrm{p}<.05]$. In other words, digital competence situations of participants differ in terms of weekly internet usage durations. There is a reasonable difference in terms of socio-economic levels $[F(2-197)=$ $4,283, p>.05]$. In other words, digital competence situations of participants differ in terms of socio-economic levels. The result is $.004<.05$ for $* \mathrm{p}<.05$ relevance level in terms of internet possession situation and the result is reasonable. In other words, digital competence situations of participants differ in terms of internet possession situations of the participants and the result is meaningful. There is a low, positive and reasonable relationship between the academic success grades and digital competence grades of students, $\mathrm{r}=.139, \mathrm{p}<.05$. Accordingly, it can be considered that as the academic success grades increase, so does the digital competence situation. When the determination coefficient $(\mathrm{r} 2=.019)$ is considered, it can be deducted that the $1,9 \%$ of total variance in the increase of academic success grades originates from the digital competence situations of students. It is possible to encounter numerous academic studies in the literature with different or similar conclusions. When the above-mentioned results are considered, it is clear that the individual differences of students influence their digital competence situations. The usage of ICT in early period constitutes an important determiner in digital competence situations' development of students. It is strongly suggested that prospective instructors who are the most important shareholders in the 
integration of ICTs into the educational system should be introduced to digital technologies and taught how to implement them in educational activities with various examples because this is very important in terms of a more efficient ICT usage in classes and education system. Moreover, it is suggested that this study shall be repeated with bigger workgroups in different universities and its results shall be implemented.

\section{Acknowledgement}

Executed summary of this research is presented in II. International Dynamic, Explorative and Active Learning IDEAL-2015 Conference.

\section{References}

Açıkgöz, Ü. K. (2005). Active learning. Izmir: Education World Publications.

Akkoyunlu, B., \& Soylu, Y. (2010). A study on teachers' digital empowerment. Turkish Librarianship, 24(4), 748-768.

Akkoyunlu, B., Soylu, M. Y., \& Caglar, M. (2010). A study on developing "Digital Empowerment Scale" for university students. Hacettepe University Journal of Education, 39(39), 10-19.

Akpinar, Y. (2003). The effect of higher education in the use of new information technologies by the teachers: the case of Istanbul schools. The Turkish Online Journal of Education Technology, 2(2), 79-96.

Ala-Mutka, K., Punie, Y., \& Redecker, C. (2008). Digital competence for lifelong learning. Institute for Prospective Technological Studies (IPTS), European Commission, Joint Research Centre. Technical Note: JRC, 48708, 271-282.

Bandura, A. (1986). Social foundations of thought and action. Englewood Cliffs, NJ: Prentice Hall.

Bawden, D. (2001). Information and digital literacies: a review of concepts. Journal of documentation, 57(2), 218-259.

Calik, T., \& Sezgin, F. (2005). Globalization, information society and education. Kastamonu Education Journal, 13(1), 55-66.

Chen, X. (2004). A study of stages of concern, layers of adoption, encouraging and obstructive factors about integrating information technology into instruction in junior high school language domain teachers in Kaohsiung City, Unpublished Master Degree Thesis, National Sun Yat-sen University, Kaohsiung, Taiwan.

Erkan,S.(2004). A survey of teachers ' attitudes toward computers. Manas Journal of Social Studies, 12.

Goktas, Y., Yildirim, Z., \& Yildirim, S. (2008). Status of ICT in schools of teacher education: Deans' views. Education and Science, 33(149), 30-50.

Hu, S., and Kuh, G. D. (2002). Being (Dis)Engaged in Educationally Purposeful Activities: The Influences of Student and Institutional Characteristics. Research in Higher Education, 43(5), 555.

Jung, I. (2005). ICT-Pedagogy integration in teacher training: application cases worldwide. Educational Technology and Society, 8(2), 94-101.

Karasar, N. (1999). Research Method. Ankara: Nobel Publishing.

Krumsvik, R. J. (2008). Situated learning and teachers' digital competence. Education and Information Technologies, 13(4), 279-290.

Mäkinen, M. (2006). Digital empowerment as a process for enhancing citizens' participation. E-learning and Digital Media, 3(3), 381-395. 
O'reilly, T. (2007). What is Web 2.0: Design patterns and business models for the next generation of software. Communications \& strategies, (1), 17.

Timur, B., Timur, S., \& Akkoyunlu, B. (2014). Determinig pre-service teachers' digital empowerment level. Mugla Sitki Kocman University Institute of Social Sciences Journal, (33), 41-59.

Yildiz, C., \& Kaya, M. K. (2012). An investigation into high school students' digital literacy level. Usak University Journal of Social Sciences, 2012,(11), 82-96.

Zhou, L., Burgoon, J. K., Zhang, D., \& Nunamaker, J. F. (2004). Language dominance in inter personal deception via computer-mediated communication. Computers in Human Behavior, 20(3), 381-402. 